\title{
Auditing of SARS-COV-2 Contagion and Transmission Protocols as a Stakeholder Management Tool
}

\author{
Gianfranco Muncinelli ${ }^{1,2 *}$, Edson Pinheiro de Lima ${ }^{1 \dagger}$, Augusto Carlos Dalla Vecchia ${ }^{2 \dagger}$, \\ Luis Moro ${ }^{2 \dagger}$, Fernando Deschamps ${ }^{1 \neq}$, Sergio E. Gouvea da Costa ${ }^{1 \neq}$ and \\ José Marcelo A. P. Cestari ${ }^{3 \neq}$ \\ ${ }^{1}$ Industrial and Systems Engineering Graduate Program, Polytechnic School, Pontifical Catholic University of Parana, \\ Curitiba, Brazil, ${ }^{2}$ Intedya-International Dynamics Advisors, Gijón, Spain, ${ }^{3}$ Programa de Pós-Graduação em Gestão da \\ Informação, Federal University of Parana, Curitiba, Brazil
}

\section{OPEN ACCESS}

Edited by:

Rodrigo Lozano,

University of Gävle, Sweden

Reviewed by:

Claudimar Veiga,

Federal University of Paraná, Brazil

Carlos Daniel López,

University of Colima, Mexico

Idoya Ferrero-Ferrero,

University of Jaume I, Spain

*Correspondence:

Gianfranco Muncinell

g.muncinelli@pucpr.edu.br

tThese authors share first authorship

¥ These authors share last authorship

Specialty section:

This article was submitted to

Sustainable Organizations,

a section of the journal

Frontiers in Sustainability

Received: 05 January 2021 Accepted: 14 April 2021

Published: 13 May 2021

Citation:

Muncinelli G, Pinheiro de Lima E, Vecchia ACD, Moro L, Deschamps F.

Gouvea da Costa SE and

Cestari JMAP (2021) Auditing of SARS-COV-2 Contagion and

Transmission Protocols as a Stakeholder Management Tool.

Front. Sustain. 2:649771.

doi: 10.3389/frsus.2021.649771
Governments and companies in all affected countries have taken measures to prevent, on the one hand, the rapid spread of the virus among the population and, on the other hand, to alleviate the economic and commercial consequences of the crisis that is already changing the daily functioning of the population and the companies. The COVID-19 pandemic has radically and unexpectedly transformed the global economic landscape. The objective of this work is to demonstrate a set of information that can meet the expectations of the internal and external stakeholders of an organization concerned with constructively relating to its stakeholders-aiming at the possibility of carrying out the work and serving customers in the context of the pandemic. The research method is the study based on the literature review process focusing on information and research systems, books, and a manufacturer's case study. It also has practical data-information collected from audits carried out. Stakeholders' expectations and interests are connected to this issue and can be aligned through an Audit of Contagion and Transmission Protocols of SARS-COV-2.

Keywords: SARS-COV-2, COVID-19, project management, stakeholder management, auditing protocol

\section{INTRODUCTION}

In recent months, society has started to face a new pandemic, in this case against the SARS-COV-2 virus, which is changing habits and customs. The pandemic is caused by a highly contagious virus against which preventive measures are required.

The most effective measures to be adopted are preventive and must comply with protocols that guarantee and demonstrate controls for the protection of organizations, which must demonstrate to workers and customers the entire responsibility and control over the virus's spread.

The COVID-19 pandemic has radically and unexpectedly transformed the global economic landscape.

Governments and companies in all affected countries have taken measures to prevent, on the one hand, the rapid spread of the virus among the population and, on the other hand, to alleviate the economic and commercial consequences of the crisis that is already changing the daily functioning of the population and the companies.

The vast majority of organizations had to temporarily close their facilities, implement teleworking in many of them or adapt to new requirements to prevent the spread of the SARSCOV-2 virus. 
The research questions that guide this work are:

RQ1. What are stakeholder expectations in the context of the COVID-19 pandemic?

RQ2. How can internal stakeholders perceive the SARS-COV-2 Contagion and Transmission Protocols Audit as a valuable element in their work performance?

RQ3. How can external stakeholders perceive the SARS-COV-2 Contagion and Transmission Protocols Audit as a valuable element in the relationship with the supplier company?

The objective of this work is to demonstrate a set of information that can meet the expectations of the internal and external stakeholders of an organization concerned with constructively relating to its stakeholders - aiming at the possibility of carrying out the work and serving customers in the context of the pandemic.

A new requirement has been established in our society: the need that organizations' facilities, regardless of their activity or sector, need to ensure the monitoring of disinfection and cleaning protocols and the implementation of safety measures related to people, processes, facilities, and products that prevent and limit the spread of coronavirus (Intedya, 2020):

1. Legal requirements required by public administrations. In this new business structure, the governments of all affected countries will oblige, not only in the market reopening phase but permanently, to all organizations, regardless of the sector, to implement specific measures in the fight against the coronavirus.

2. Recommendations from international organizations. Organizations like the WHO, guaranteeing society's safety worldwide and having information about the progress of the pandemic and against it, constantly update and publish new strategies for the prevention and treatment of the coronavirus.

3. The Covid 19 pandemic generated great concern in everyone regarding contagion. We all pay the utmost attention to following new habits of prevention, hygiene, and disinfection. This changes the market, as all customers become judges of organizations' management of these factors. All companies must generate trust in customers, demonstrating and evidencing compliance with protocols.

4. Responsibility of all organizations regarding the health of our workers. In addition to the applicable legal requirements, companies must protect their most precious people from the point of view of corporate social responsibility and from the point of view of business continuity.

5. Companies must ensure that their products and services comply with the strictest international controls and standards in the fight against the spread of the SARS-VOC-2 virus.

6. Organizations need to protect themselves, not only from administrative sanctions but also from possible civil and criminal responsibilities.

There are expectations from stakeholders about these new requirements, which can be managed by carrying out audits.

We know that the academic literature is still starting on the specific topic and that there is a need for many more studies of an empirical nature (surveys, case studies, panels with specialists, among others) to elucidate and scientifically prove a more detailed framework. It was decided to write about this subject in order to collaborate with the actions against COVID 19. The main idea is to bring a little about the models that are being developed by the consulting companies that, in reality, are adapting the solutions to address the problems imposed by COVID 19.

\section{RESEARCH DESIGN}

The research method is the study based on the literature review process focusing on information and research systems, books, and a manufacturer's case study. It also has empirical datainformation collected from audits carried out. The data analysis uses the triangulation mechanism to produce an evaluation exercise of the audit project management practices adopted by the company.

This study was carried out in collaboration with the Brazilian office of Intedya - International Dynamics Advisors, a company that developed the audit product for the SARS-COV-2 contagion and transmission protocols.

The literature provides some guidelines, highlighting the work of Niekerk and Getz (2019).

- Design the ongoing planning process for stakeholder management: where to start with stakeholder theory

- Determine what questions to ask during the process about internal and external stakeholders

- Perform stakeholder mapping

- Classify stakeholders according to legitimacy, power, and urgency, and their interests and ability to influence or collaborate with the focal organization

- Formulate a stakeholder strategy

- Evaluate a combined strategy matrix

- Understand the purpose of contracts with stakeholders

The PRINCE2 framework shows that it is necessary to define the stakeholder engagement approach, determining how the project is effectively involved with the stakeholders, including determining the responsibilities for communication and the key messages that need to be conveyed. For each stakeholder, the following elements must be agreed upon (Melo, 2015):

- Information that the interested party needs from the project

- Information that the party needs to provide to the project

- Communication method, format, and frequency

- Sender and recipient of the communication

Figure 1 shows the survey design. Questions to ask before developing the plan:

- What are the strategic reasons for consulting stakeholders at this stage?

- Who needs to be consulted?

- What are the priority issues?

- What will be the most effective methods of communicating with stakeholders? 


\section{Research Questions}

RQ1. What are stakeholder expectations in the context of the COVID-19 pandemic?

RQ2. How can internal stakeholders perceive the SARS-COV-2 Contagion and Transmission Protocols Audit as a valuable element in the performance of their work?

RQ3. How can external stakeholders perceive the SARS-COV-2 Contagion and Transmission Protocols Audit as a valuable element in the relationship with the supplier company?

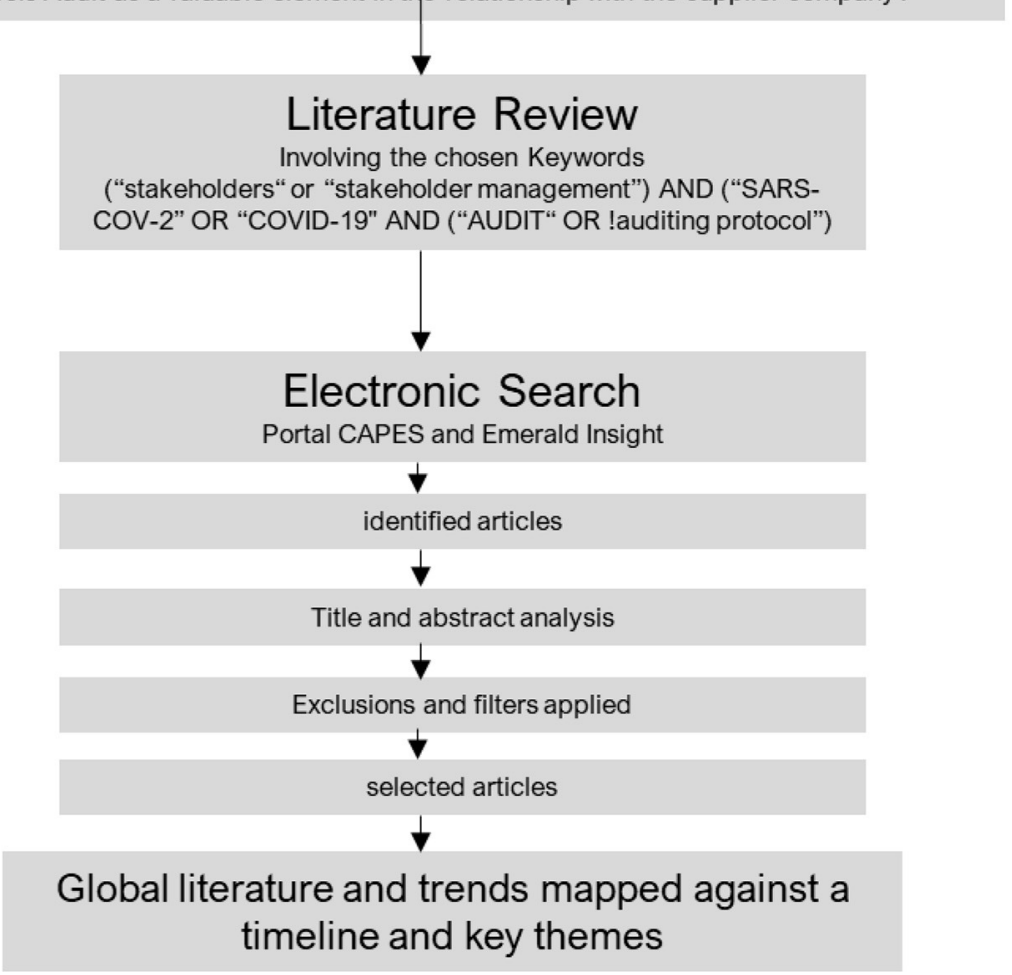

FIGURE 1 | Research design

- Who within the company is responsible for what activities?

- Are there any other engagement activities that will take place within the proposed timeframe (perhaps with other sections of your organization)?

- How will the results be captured, tracked, reported, and disseminated?

Recalling that the audit data in the SARS-COV-2 contagion and transmission protocols are binary-whether or not the requirement is met.

\section{STAKEHOLDERS}

Stakeholder theory suggests that an organization will be more sustainable when addressing stakeholder interests and perform better (Freeman et al., 2007a,b, 2010; Niekerk, 2016).

Stakeholder management is the process by which you organize, monitor, and improve your relationships with stakeholders. It involves the systematic identification of stakeholders, analyzing your needs and expectations, and planning and implementing various tasks to engage with them. A good stakeholder management process will be how you will coordinate your interactions and assess the status and quality of your relationship with the various stakeholders (Freeman, 1994).

Most stakeholder management definitions tend to focus on the idea that you can "manage your stakeholders (so that they do what you want)." The emphasis is placed on creating a stakeholder management plan that maps the stakeholders' level of interest and influence and lists various levels of engagement for different groups. It is a plan that is usually created at the beginning of the project and then filed to accumulate dust (Freeman, 1994). In most cases, there is a legal and strategic objective to carry out stakeholder engagement / consultation / management. You may have a statutory or legal requirement to consult (Freeman et al., 2018).

There are two groups of stakeholders in the project, internal and external to the organization. The most commonly recognized type is external stakeholders; however, internal stakeholders' management is often more problematic (Vogwell, 2003).

\section{Internal Stakeholders}

On specific projects, it can be challenging to identify who the customer really is, there may be a single point of contact 
named, but that person is not really the "customer," just the representative of the customer's organization. Often, this person has a responsibility to reconcile a wide range of different requirements within the client organization, and, as a result, they will be subject to many influences that can affect the project as a change. Within the client's organization, there will be a whole range of individuals with very different "interests" in the project; unless the appointed client's representative adopts a very strong line, they will succeed in influencing the course of the project (Vogwell, 2003).

The client organization is made up of a whole range of individuals with different wants and needs that constitute a "multifaceted" client. In these situations, the decision-making process becomes complex. Questions cannot be answered directly by the designated customer's single point of contact. This single point of contact must negotiate with the various other stakeholders within the client's organization to obtain an answer (Vogwell, 2003).

That is why these moments, the obligation to ensure compliance with regulations and the health of workers, become a necessity and an exercise of corporate responsibility, which, if not forgotten, can be criminally condemned for the omission of the measures that guarantee the development of work in conditions of safety and hygiene, so that, with this lack of adoption, the life, health or physical integrity of workers are placed at serious risk, as provided for in Articles 316 and 317 of the Penal Code. And while it is true that the risk of contagion from Covid-19, with the exception of the health sector, is not a risk derived from the activity (Gallego, 2020).

\section{External Stakeholders}

External stakeholders are individuals or organizations that are not part of the client's organization but are nevertheless interested in the project. They are perhaps the most easily recognized stakeholder groups. For publicly funded projects, the number of stakeholders that can be identified is high. They generally consist of the types shown by Vogwell (2003):

- Funders, whether government departments, donations, or private sector partners.

- Users, whether they are passengers of a transport project or visitors to a museum.

- Regulatory authorities. Most commonly, planning authorities, but also specialized regulatory authorities.

- Those affected may be neighbors or people who work or live nearby.

- The press and the media are other significant groups that can significantly influence the perception of the project and its perceived and, in some cases, real success.

- Customers and users of products and services.

In this work, the focus is basically on the users (customers) of the organization's services and products that are auditing the SARS-COV-2 contagion and transmission protocols. In any case, it is not absurd to claim that managing the stakeholder environment is a highly complex management task.

\section{AUDIT AND STAKEHOLDERS}

According to Miles (2012) and Abdullah and Valentine (2009), the theory of stakeholders implies that, in addition to the traditional shareholders of organizations, other parties are involved: any group or individual that can affect or is affected by the achievement of the objectives of a company. Where the normative approach to stakeholder theory is linked to corporate social responsibility and business ethics, the instrumental approach uses empirical data to identify the connections that exist between managing stakeholder groups and achieving efficiency goals (Donaldson and Preston, 1995). The instrumental approach to stakeholder theory is applied in the investigation of the relationship management with the internal audit stakeholders to create a positive relationship with all stakeholders through the proper management of their respective expectations.

Many studies have investigated stakeholder relationship management from an internal audit perspective; for example, D'Onza and Sarens (2017) investigated the quality of the relationship between internal and audited auditors, and Abbott et al. (2017) investigated the effect of the audit committee's relationship with a focus on internal controls. Blattberg (2004) criticizes the theory of interested parties, arguing that interested parties' various interests will always be compromised or balanced with each other.

The main strategy should be to identify who the stakeholders are, their expectations, identify the performance gap, prioritize their demands and develop responses to meet the expectations of these stakeholders, especially from senior management and the audit committee (Paape et al., 2003). Internal audit will always operate in the contradictory domains of, on the one hand, being part of the organization and, on the other hand, trying to remain independent and objective in order to increase its effectiveness (Hoos et al., 2013).

To support Blattberg's argument (Blattberg, 2004), studies indicate that there can be much conflict between the needs of two stakeholders (Paape et al., 2003; Van Peursem, 2004; Hoos et al., 2013). Studies indicate that management needs take precedence over those of the executive authority (Van Peursem, 2004; Sarens and De Beelde, 2006; Sarens et al., 2009), also applicable to the public sector (Roussy, 2013). Therefore, it can be assumed that these conflicting needs of key internal audit stakeholders can affect how they perceive the internal audit's effectiveness.

\section{THE AUDIT PROCESS}

Several authors emphasize the tension between external stakeholders' interests and audit clients, including Ijiri (1975) and Lee (1993). However, the position of auditors in relation to these two parties is a basis for stakeholders and customers to view the audit work in different ways. Hellman's (2006) article focuses on the audit client's point of view and recognizes that it may be insufficient to consider only clients' perceptions of their satisfaction. Daugherty and Tervo (2008) and Cameran and Moizer (2010) argue that customers can be satisfied with an audit without considering what is helpful for owners and other external stakeholders. However, most audit surveys focusing 


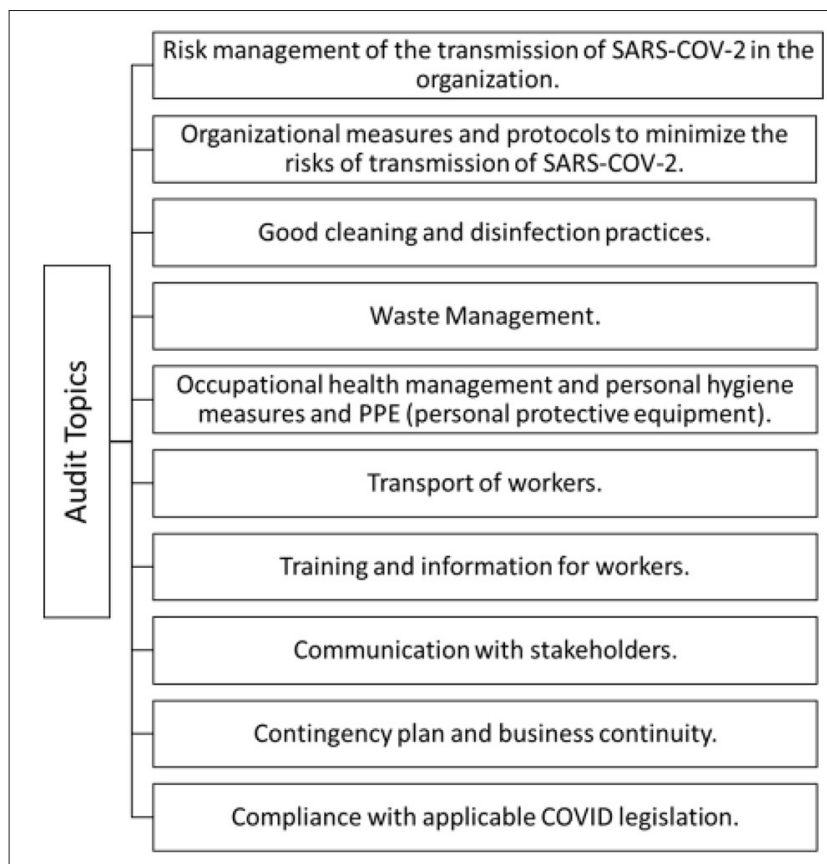

FIGURE 2 | Audit control points (Intedya, 2020).
6. Are there disinfection solutions at the entrance and in common areas (dining rooms, bathrooms, meeting rooms, work areas, etc.)?

7. Is there control over the use of these disinfectants by people before accessing these areas?

8. Is the availability and availability of soap, gels, hand dry paper, the proper functioning of equipment such as dispensers checked daily, and is it documented?

9. Is staff outside the company informed of established hygiene procedures before access?

10. Is it available in the bathroom gel alcohol gel for anyone who accesses the facilities (customers, subcontractors, etc.)?

11. In companies at risk of occupational exposure to SARSCov-2, are PPE (Personal Protective Equipment) used in the preventive documentation used, and are the work protocols for tasks with risk of contagion fulfilled?

12. Is it guaranteed that Personal Protective Equipment is not shared or reused under any circumstances?

The whole process can be found in the original in Spanish at https://www.intedya.com/internacional/diagnostico-covid. php.

\section{THE STAKEHOLDER BENEFITS}

Internal stakeholders are basically employees. It is necessary to give them satisfaction in order to show that they are working in a safe place, where there are adequate protocols that preserve their physical integrity (and consequently their emotional integrity). There is an appreciation of the employee, bringing tranquility and productivity. Remembering that there is a substantial benefit to the employer, as an audit/certification can be used as an instrument to mitigate legal risk in the case of a labor action.

Risk can be defined as "the occurrence of an event that has consequences or impacts on a particular project" (Kleim and Ludin, 2000). This definition implies a fundamental characteristic of risk, namely, uncertainty. Specifically, there is a likelihood that the risk event may occur and could result in an impact on business processes that may result in substantial losses.

Organizations, in general, face increasingly challenging legal risks, including the fact that regulatory requirements are becoming more stringent. This results in a complex operating environment that exposes organizations to a greater variety of legal risks than those that would arise from normal day-to-day operations and decision-making processes. When organizations manage their legal risks, they are in a position beyond just meeting legal and contractual requirements. They really create value for their stakeholders.

There are also external stakeholders to be considered, especially customers, users of products and services. These precious customers who need to return to the premises and need to feel safe eating meals. They need to feel safe when being attended by employees (waiters, attendants, etc.) and using the facilities - as they identify suitable protocols related to contagion and transmission, which ensure that products and services meet the strictest controls and standards based on 
international organizations. in the fight against the spread of the SARS-COV-2 virus.

In a way that broadly serves stakeholders, the following benefits are listed below:

- A real and urgent market need.

- Reduces the risk of spreading the SARS-COV-2 virus.

- Increases protection for customers, workers, products, and services.

- Creates trust in all our stakeholders.

- Monitors compliance with applicable legislation.

- You can avoid sanctions and / or potential civil or criminal liability.

- Demonstrable to third parties.

- VERIFIABLE online certificate and protected against counterfeiting by exclusive numbering and QR code.

- The audits are carried out according to the methodology established by the international reference regulations under the indications of ISO 19011: 2018.

- Compatible and complementary with other existing standards and good practices.

- Compatible and integrable with other health and safety standards.

- Considers national and international regulations and/or standards.

Stakeholders' expectations and interests are connected to this issue and can be aligned through an Audit of Contagion and Transmission Protocols of SARS-COV-2.

In order to guarantee the smoothness of the process, the recording of audit evidence is carried out in real-time through the Intedya system, eliminating the possibility of adulteration or fraud. Stakeholders have a channel for reporting and reporting possible violations that can lead to extraordinary audits or certification withdrawal.

\section{CONCLUSION}

A new requirement has been established in our society: the need that all facilities of all organizations, regardless of their activity or sector, need to ensure the monitoring of disinfection and cleaning protocols and the implementation of safety measures related to people, processes, facilities, and products that prevent and limit the spread of coronavirus.

Stakeholders' needs/expectations are associated with a real and urgent market need; reduces the risk of spreading the SARS-COV-2 virus; increases protection for customers, workers, products, and services; creates trust in all our stakeholders; monitors compliance with applicable legislation; can avoid sanctions and / or potential civil or criminal liability; demonstrable to third parties; VERIFIABLE online certificate and protected against counterfeiting by exclusive numbering and QR code; audits are carried out according to the methodology established by the international reference regulations under the indications of ISO 19011: 2018; compatible and complementary to other existing standards and good practices; compatible and integrable with other health and safety standards and considers national and international regulations and / or standards.

\section{Next Steps}

Several aspects can be included in future research, such as: include a shareholder balance scorecard, where companies and sectors can establish their key variables in a pandemic situation as well as a new term aimed at suppliers, where capabilities and resources must be integrated to be more effective in satisfying the end customer. Include some of the theories of organizational design related to the complex decision-making process by top managers.

\section{Limitations}

(a) In complex decisions, the audit information can cause some confusion for the allocation of resources, especially in new product lines or partnerships, where there may be interdependence of resources. (b) The information of the majority of interested parties is probably aligned with the current reality's actual interests. In this sense, relevant information can be omitted, hampering decision-making. (c) The audit instrument must be operated and analyzed by a specialist. (d) Consider different sectors of the business environment.

\section{Forces}

(a) The information is likely to be relevant for making alliances or other types of strategies, especially in those organizations that have complex decisions in the allocation of resources and levels of dependencies. (b) The information is likely to be useful to highlight the decisions that must be made in crisis or complex situations, such as those of power, trust, and governance among internal stakeholders. (c) The information obtained could mitigate the risks related to highly contagious diseases such as COVID19 or those neglected and emerging. (d) The information is likely to provide information relevant to the solution of situations that fall into certain sectors or related companies. (e) Information can be beneficial for financial institutions as they can proactively and timely control and control the risks associated with the COVID 19 pandemic. (f) The information can be useful for the adoption of situations of resilience and optimism for companies. (g) The information will be extremely useful for public managers in defining new public policies in times of crisis. (h). Interesting information for Business to Business companies. According to the audit results, it is recommended to carry out a stakeholder control panel where the key variables of success in the possible redefinition of the business that benefit not only the company, but society itself are identified. (i) The information is likely to identify and take underestimated risks, especially from internal stakeholders.

\section{AUTHOR CONTRIBUTIONS}

All authors listed have made a substantial, direct and intellectual contribution to the work, and approved it for publication. 


\section{REFERENCES}

Abbott, L. J., Parker, S., and Peters, G. F. (2017). Serving two masters: the association between audit committee internal audit oversight and internal audit activities. Account. Horiz. 24, 1-24. doi: 10.2308/acch.2010.24.1.1

Abdullah, H., and Valentine, B. (2009). Fundamental and ethics theories of corporate governance. Middle East. Finan. Econ. 4, 88-96.

Blattberg, C. (2004). Welfare: Towards the Patriotic Corporation - From Pluralist to Patriotic Politics: Putting Practice First. New York, NY: Oxford University Press.

Cameran, M., Moizer, P., and Pettinicchio, A. (2010). Customer satisfaction, corporate image, and service quality in professional services. Serv. Ind. J. 30, 421-435. doi: 10.1080/02642060802236111

Daugherty, B. E., and Tervo, W. A. (2008). Auditor changes and audit satisfaction: client perceptions in the Sarbanes-Oxley era of legislative restrictions and involuntary auditor change. Crit. Persp. Acc. 19, 931-951. doi: 10.1016/j.cpa.2005.09.003

Donaldson, T., and Preston, L. E. (1995). The stakeholder theory of the corporation: concepts, evidence, and implications. Acad. Manage. Rev. Acad. Manage. 20:71. doi: 10.5465/amr.1995.9503271992

D'Onza, G., and Sarens, S. (2017). Factors that enhance the quality of the relationships between internal auditors and auditees: evidence from Italian companies. Int. J. Auditing. Available online at: http://onlinelibrary.wiley.com/ journal/10.1111/(ISSN)1099-1123/earlyview (accessed September 30, 2017).

Freeman, R. E. (1994). The politics of stakeholder theory: some future directions. Bus. Ethics Q. 4, 409-422. doi: 10.2307/3857340

Freeman, R. E., Harrison, J., and e Wicks, A. (2007b). Managing for Stakeholders: Business in the 21st century. New Haven, CT: Yale University Press.

Freeman, R. E., Harrison, J. S., and Wicks, A. C. (2007a). Managing for Stakeholders: Survival, Reputation, and Success. New Haven, CT: Yale University Press.

Freeman, R. E., Harrison, J. S., Wicks, A. C., Parmar, B. L., and de Colle, S. (2010). Stakeholder Theory: The State of the Art. Cambridge: Cambridge University Press. doi: 10.1017/CBO9780511815768

Freeman, R. E., Philips, R., and Sisodia, R. (2018). Tensions in Stakeholder Theory. Business \& Society. doi: 10.1177/0007650318773750

Gallego, L. E. (2020). A Importância do Compliance nas Empresas Diante da Crise do Covid-19. Available online at: http://www.worldcomplianceassociation. com/noticias.php?id=2753andutm_source $=$ dlvr.itandutm_medium $=$ linkedin\# googtrans(es|pt) (accessed December 30, 2020).

Hellman, N. (2006). Auditor-client interaction and client usefulness: a Swedish case study. Int. J. Audit. 10, 99-121. doi: 10.1111/j.1099-1123.2006.00345.x

Hoos, F., Kochetova-Kozloshi, N., and D’Arcy, A. (2013). Serving two masters' and the chief audit executive's communication: experimental evidence about internal auditors' judgment. SSRN Electron. J. Available online at: http://papers. ssrn.com/sol3/papers.cfm?abstract_id=2302269 (accessed December 3, 2013). doi: $10.2139 /$ ssrn. 2302269

Ijiri, Y. (1975). Theory of Accounting Measurement. Sarasota, FL: American Accounting Association.

Intedya (2020). International Dynamic Advisors. Available online at: www.intedya.com (accessed December 30, 2020).

Kleim, R. L., and Ludin, I. S. (2000). Reducing Project Risks. Aldershot: Gower.
Lee, T. A. (1993). Corporate Audit Theory. London: Chapman and Hall.

Melo, J. L. (2015). Guia Preparatório Para a Certificação Prince2 Foundation. Rio de janeiro: Novaterra.

Miles, S. (2012). Stakeholders: essentially contested or just confused? J. Bus. Ethics 108, 285-298. doi: 10.1007/s10551-011-1090-8

Niekerk, M. V. (2016). The applicability and usefulness of the stakeholder strategy matrix for festival management. Event Manage. 20, 165-180. doi: 10.3727/152599516X14610017108666

Niekerk, M. V., and Getz, D. (2019). "Chapter 3 generic stakeholder management strategies," in Event Stakeholders, eds M. V. Niekerk, and D. Getz (Oxford: Goodfellow Publishers), 54-57. doi: 10.23912/9781911396635-4092

Öhman, P., Häckner, E., and Sörbom, D. (2012). Client satisfaction and usefulness to external stakeholders from an audit client perspective. Managerial Auditing J. 27, 477-499. doi: 10.1108/02686901211227995

Paape, L., Scheffe, J., and Snoep, P. (2003). The relationship between the internal audit function and corporate governance in the EU: a survey. Int. J. Auditing 7, 247-262. doi: 10.1046/j.1099-1123.2003.00073.x

Roussy, M. (2013). Internal auditor's roles: from watchdogs to helpers and protectors of the top management. Crit. Perspect. Accounting. 24, 550-571. doi: 10.1016/j.cpa.2013.08.004

Sarens, G., and De Beelde, I. (2006). The relationship between internal audit and senior management: a qualitative analysis of expectations and perceptions. Int. J. Auditing 10, 219-241. doi: 10.1111/j.1099-1123.2006.00351.x

Sarens, G. S., De Beelde, I., and Everaert, P. (2009). Internal audit: a comfort provider to the audit committee. Br. Accounting Rev. 41, 90-106. doi: 10.1016/j.bar.2009.02.002

US Department of Labour (2020). OSHA 3992-03 2020 Guía Sobre la Preparación de los Lugares de Trabajo para el Virus COVID-19. Available online at: https:// www.osha.gov/Publications/OSHA3992.pdf (accessed January 1, 2021).

Van Peursem, K. (2004). Internal auditors' role and authority: New Zealand evidence. Managerial Auditing J. 19, 378-392. doi: 10.1108/026869004105 24382

Vogwell, D. (2003). "Stakeholder management," in Paper presented at PMI® Global Congress 2003-EMEA, The Hague, South Holland, The Netherlands (Newtown Square, PA: Project Management Institute).

Conflict of Interest: The authors declare that the research was conducted in the absence of any commercial or financial relationships that could be construed as a potential conflict of interest.

The reviewer CV declared a shared affiliation, though no other collaboration, with one of the authors JC to the handling Editor.

Copyright (C) 2021 Muncinelli, Pinheiro de Lima, Vecchia, Moro, Deschamps, Gouvea da Costa and Cestari. This is an open-access article distributed under the terms of the Creative Commons Attribution License (CC BY). The use, distribution or reproduction in other forums is permitted, provided the original author(s) and the copyright owner(s) are credited and that the original publication in this journal is cited, in accordance with accepted academic practice. No use, distribution or reproduction is permitted which does not comply with these terms. 